\title{
INFORMATION LITERACY IN THE LAW CURRICULUM: EXPERIENCES FROM CARDIFF
}

\author{
By JACKIE DAVIES* and CATHIE JACKSON**
}

It is often said that the library is to a law student what the laboratory is to the scientist. ${ }^{l}$ Are we teaching students not only to find their way around this "laboratory", both physical and virtual, but to evaluate what they find and use it effectively? Skills of research, analysis, synthesis and presentation are fundamental to the successful study of law and beyond. How can we ensure that students develop these skills without sacrificing substantive content in an already crowded curriculum? This paper discusses the concept of "information literacy" and how Cardiff Law School used the concept to integrate legal research, IT and other legal skills training into a coherent module with an English Legal System focus.

\section{Information literacy - the concept}

Information literacy is most commonly defined as the skills needed for a person to "be able to recognize when information is needed and have the ability to locate, evaluate, and use effectively the needed information". ${ }^{2}$ The term is relatively recent to the UK, having first come into regular usage around 1999. At that time, SCONUL, the society representing UK university libraries, produced its own "Seven Pillars" model ${ }^{3}$ of information literacy, referring back to the already well-established information literacy guidelines produced by the Association of College and Research Libraries (ACRL), part of the American Library Association. The ACRL listed five competency standards for an information literate student (Figure 1), detailing, for each standard, example performance indicators and, most usefully, learning outcomes.

\footnotetext{
* Lecturer in Law, Cardiff Law School.

** Senior Consultant: Information Literacy and Information Specialist: Law, Information Services, Cardiff University

${ }^{1}$ First espoused by Prof. Langdell at the "quarter-milliennial" celebration of Harvard University on $5^{\text {th }}$ November 1886, reprinted in (1887) 3 L.Q.R. 118 at page 124.

2 American Library Association. (1989) Presidential Committee on Information Literacy: Final Report http://www.ala.org/ala/acrl/acrlpubs/whitepapers/presidential.htm All web links in the footnotes checked on 12 April 2005.

${ }^{3}$ SCONUL Advisory Committee on Information Literacy. (1999) Information Skills in Higher Education: A SCONUL Position Paper. Society of College, National and University Libraries http://www.sconul.ac.uk/activities/inf lit/papers/Seven pillars2.pdf
} 
Figure 1: ACRL Information Literacy Competency Standards for Higher Education ${ }^{4}$

The information literate student:

1. determines the nature and extent of the information needed;

2. accesses needed information effectively and efficiently;

3. evaluates information and its sources critically and incorporates selected information into his or her knowledge base and value system;

4. individually, or as a member of a group, uses information effectively to accomplish a specific purpose;

5. understands many of the economic, legal and social issues surrounding the use of information and accesses and uses information ethically and legally.

The individual skills which comprise information literacy are already recognised as skills to be developed in the undergraduate law degree. The QAA benchmark standards for law (Figure 2) include, as subject-specific abilities:

Application and Problem-Solving:- "a student should demonstrate a basic ability to apply her or his knowledge to a situation ... in order to provide arguable conclusions for concrete problems."

Sources and Research:- "a student should demonstrate a basic ability

to identify accurately the issue(s) which require researching;

to identify and retrieve up-to-date legal information, using paper and electronic sources;

to use primary and secondary legal sources relevant to the topic under study.",

Similarly, the general transferable intellectual skills and key skills cover ground which can be described as information literacy.

\footnotetext{
${ }^{4}$ Association of College and Research Libraries (2000) Information Literacy Competency Standards for Higher Education. Chicago, Illinois: American Library Association.

http://www.ala.org/ala/acrl/acrlstandards/standards.pdf
} 
Figure 2: QAA benchmark areas of performance for law ${ }^{6}$

\section{$\underline{\text { Subject specific abilities }}$}

Knowledge

Application and problem solving

Sources and research

$\underline{\text { General transferable intellectual skills }}$

Analysis, synthesis, critical judgement and evaluation

Autonomy and ability to learn

$\underline{\text { Key skills }}$

Communication and literacy

Numeracy, IT and teamwork

The Joint Statement by the Law Society and Bar Council on what constitutes a qualifying law degree added five "knowledge" areas and eight "general transferable skills" to the requirements of the QAA Benchmark Standards. The latter skills include abilities to:

iii. $\quad$ select key relevant issues for research and formulate them with clarity;

iv. use standard paper and electronic resources to produce up-to-date information;

vii. conduct efficient searches of websites to locate relevant information; exchange documents by email and manage information exchanges by email;

viii. $\quad$ produce word-processed text and present it in an appropriate form. ${ }^{7}$

All law schools teaching the qualifying law degree will, therefore, be addressing these skills at some point during the teaching programme. However, skills teaching can appear "bolt-on"

\footnotetext{
${ }^{5}$ Quality Assurance Agency for Higher Education. (2000) Academic Standards - Law. Gloucester: Quality Assurance Agency for Higher Education. Available on the web at www.qaa.ac.uk/academicinfrastructure/benchmark/honours/law.pdf

${ }^{6}$ Quality Assurance Agency for Higher Education (2000) op cit.

${ }^{7}$ Law Society and General Council of the Bar (1999) Joint Statement issued by the Law Society and the General Council of the Bar on the completion of the initial or academic stage of training by obtaining an undergraduate degree. www.legaleducation.org.uk/downloads/ja.pdf
} 
and irrelevant to the course if not closely integrated into the curriculum. The limited evidence currently available suggests that such integration may often not be achieved. In two-thirds of UK law schools, students are taught IT skills by staff elsewhere in the institution and in only just over one third of schools did law tutors have any responsibility at all for IT training. ${ }^{8}$ Similarly, in a third of law schools, a librarian is teaching legal research skills without any integration into the curriculum. In 59\% of institutions the librarian contributes to a module, although even then the skills may still appear "bolt-on" to the student if not fully embedded into the rest of the activities and assessment of the module. ${ }^{9}$

The concept of information literacy offers a model through which essential skills training can be embedded into law teaching. However, incorporating information literacy into the curriculum requires collaboration across disciplines. The librarian collects, organises and maintains access to information from its many sources, and supports students and staff who seek information. ${ }^{10}$ Librarians offer expertise in accessing information effectively and efficiently (Standard 2 of the ACRL Informa tion Literacy Competency Standards shown in Figure 1). Law school IT staff, where available, provide the specialist law applications, maintain the hardware and train and support students on a daily basis. The IT skills they offer underpin all aspects of information literacy. However, only with the active collaboration of the law tutor, can such legal research and IT training be seen by law students as relevant and applicable to their studies. It is the law tutor who establishes the context in which the learning takes place and the expectations of the students. It is the law tutor too, who plans the progression of the curriculum, monitors progress and who has the skills and remit to develop the higher order skills in the student of analysis and application of information to the legal context. By pooling the expertise of law librarian, IT specialist and law tutor at both planning and delivery stages, skills training can be delivered and information literacy standards met, without sacrificing substantive content.

\footnotetext{
${ }^{8}$ Data provided from the UK Law Schools Survey 2004, to be published in a forthcoming issue of Law Teacher.

9 Jackson, C. (2002) SPTL/BIALL Academic Law Library Survey 2000/2001. Legal Information Management 2(2), 38 at p. 47
} 


\section{Information Literacy - the institutional context}

In 2000 the Information Services division at Cardiff University presented a Learning and Training Policy, having been briefed to develop an innovative approach to training to meet the requirements of the newly converged library and computing services. After considering the European Computer Driving Licence ${ }^{11}$ and the newly emerging SCONUL "Seven Pillars" model $^{12}$ the division decided to adopt the established ACRL model noted above in Figure 1, with its five standards and example learning outcomes already prepared. The resulting policy tied IT and information skills together as stepping stones towards the University's mission of research-led learning and teaching, as illustrated in Figure $3 .^{13}$

Figure 3: Diagrammatic representation of the place of information literacy within the learning and teaching mission of Cardiff University

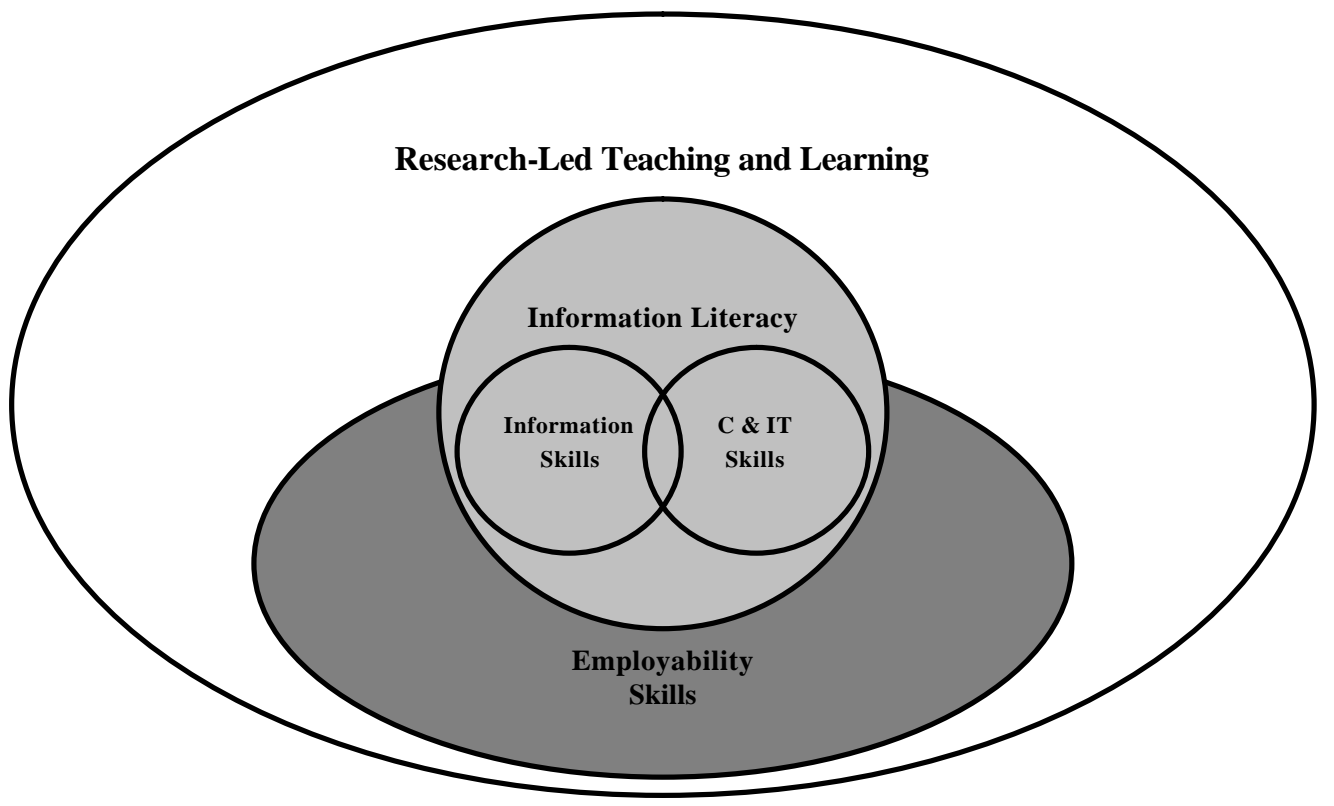

\footnotetext{
${ }^{10}$ Association of College and Research Libraries (2000) op cit. p. 4

11 see $\underline{w w w . e c d l . c o m}$

12 SCONUL Advisory Committee on Information Literacy. (1999) op cit

${ }^{13}$ Griffiths, S. and Jackson, C. (2002) A Framework for Change: The Development and Implementation of an Information Literacy Policy at Cardiff University. Presentation to the $1^{\text {st }}$ International Conference on IT \& Information Literacy, Glasgow. http://www.elit-conf.org/itilit2002/papers/ab11.html Diagram inspired by the Florida International University Libraries' Information Literacy Initiative www.fiu.edu/ library/ili/ilibroc.html which placed Technology at the centre, then Information Literacy, leading to Critical Thinking.
} 
The policy recognised the value of information literacy as a basis for lifelong and selfdirected learning as well as a key employability skill. The policy paper was appendixed by three scenarios to illustrate the application of the approach for an undergraduate student, a PhD student and a member of the administrative support staff. ${ }^{14}$ Each scenario was followed by learning outcomes for each information literacy standard, based on those provided by the ACRL.

In 2002 the Learning and Training Policy was endorsed by the University's own Teaching and Learning Committee who approved it as University policy. A Guidance Note was produced to facilitate implementation of the policy across the University. ${ }^{15}$ A key argument of the Guidance Note was that information literacy skills should be embedded into the academic curriculum and not be treated as a 'bolt-on' set of generic skills. The scenarios from the Learning and Training Policy were welcomed by the University's committee in demonstrating how the standards could be applied and so were included in the Guidance Note. The importance of establishing collaboration between all those involved in the learning and teaching process in order to achieve this integration was also stressed.

\section{Information Literacy in Cardiff Law School}

The Law School were the first to embed information literacy learning outcomes into a module at Cardiff University. Legal Foundations has been running for four years and is a compulsory, semester one module for the 230 first year law students, including approximately 70 international students. The module, recently upgraded from 20 to 30 credits, introduces students to the main features of the legal system in England and Wales and develops the basic legal skills needed in the study of law. ${ }^{16}$

\footnotetext{
${ }^{14}$ An example of the scenarios and associated learning outcomes is available in SCONUL. (2004) Learning Outcomes and Information Literacy. Higher Education Academy. p. 24 http://www.sconul.ac.uk/activities/inf_lit/papers/outcomes.pdf and in the Cardiff University Guidance Note (see footnote 15 below)

${ }^{15}$ Teaching and Learning Committee. (2002) Information Literacy Guidance Note. Cardiff: Cardiff University http://www.cardiff.ac.uk/schoolsanddivisions/divisions/learning/guidance/infolit.html

16 The module's aims and learning outcomes are available in SCONUL (2004) op cit.
} 
The module has evolved over a decade and a half from a substantive English Legal System course with a limited library skills element, through a pure skills course to its present form which attempts to embed skills within a substantive framework.

The pure skills progenitor ran as a seminar-only course with only two lectures on the substantive law. A number of problems were identified with this module. Students were expected to acquire substantive subject-based knowledge from recommended reading, but evidence suggested that they did not do so. IT skills were introduced for the first time, but the sessions were seen as a "bolt-on" by both students and staff. Library skills were expanded to include electronic sources, but there was similarly no real attempt to integrate these sessions with other elements of the course. The result was a module that lacked substance, regarded by students as of lesser significance than substantive courses where they learnt "real law". There was a need to re-introduce substantive content to restore a knowledge component to meet QAA benchmarks, but a reluctance to abandon the skillsbased ethos of the course which placed emphasis on student-led group and individual activities as a vehicle for learning.

The review of this module coincided with the development of the Learning and Training Policy within Information Services. The QAA benchmarks were revisited by the module leader as the starting point for restructuring the module and the similarity between these and the information literacy standards became apparent. The model provided a way to retain the skills elements, but to embed them into a substantive law course. The core of the Legal Foundations module is now built around the concept of information literacy, with collaboration between the module leader, the law librarian and the Law School's computing officer.

Assessment was originally through an essay and a casenote, of equal weighting. Following the move to a 30 credit rating, assessment is now through an essay, accompanied by a "research trail", and by an exam in two parts: the first comprising multiple choice questions to test subject-specific knowledge; the second a case analysis exercise to assess legal reasoning skills.

The syllabus of the revised module is divided into four units: the legal system of England and Wales; legal analysis and reasoning skills; legal research skills; and legal presentation skills. 
The four units are underpinned by two IT skills sessions which introduce students to the University network, word-processing, email, search engines, IOLIS and to on-line exercises, quizzes and self-tests. A lecture and exercises in week 1 outline how legal information is structured. These skills are pre-requisite to further learning in information literacy.

The legal system unit is subject specific, taught through 15 lectures intended to foster subjectrelated knowledge and to supply a context for the skills-based elements of the course. Running parallel, three two-hour seminars comprise the legal analysis unit and combine practical exercises of legal analysis and discussion.

The final two units in the module build on this legal knowledge through the information literacy approach. The legal research skills unit commences with a large group presentation by a Westlaw trainer. This gives the students an overview of how to search one of the largest legal databases, a skill which they will later transfer to other databases. Another lecture, from the module leader, covers citation and referencing for law, directing students to the University's rules on proper citation and the avoidance of plagiarism, to the writing skills resources on the University's electronic skills bank and to a selection of texts on writing for law.

Five two-hour seminars over the next six weeks take students progressively through the information literacy standards, yet also enhance the students' knowledge and understanding of substantive aspects of law as they research aspects of the criminal and civil justice systems in more detail. In two of the seminars they work as teams, in the first supported by the law librarian. Thereafter they are given independent research tasks. They are asked to use the information they have found to complete a series of tasks, presenting their research in both oral and a variety of written formats.

The starting point for the first seminar is a hypothetical scenario leading to the group research exercise. The topic of the scenario is selected both for relevance to the substantive syllabus and for the breadth of information resources available for students to research. An example scenario follows:

The government is considering abolishing the defendant's right to elect trial by jury for offences triable 'either way'. It suspects that Crown Court trials are more expensive 
than trial at magistrates' courts. It also believes that the right is being manipulated by defendants to evade conviction.

Each group is briefed by their tutor and divided into two teams of lawyers: one representing Liberty; the other, the Police and "Justice for Victims", a fictional interest group. The teams are told that the government wishes to consult both groups before taking legislative action and that it has asked each to present a brief oral report on its proposals and concerns. They are also told that in a future seminar, they will be asked to pool their research with other members of their team and present a report.

The first of the five seminars takes place in a PC room and is led by a law librarian, students having been instructed to conduct background reading on jury trials using textbooks in preparation. The range of materials to consider when planning a research strategy (textbooks, journals, primary legislation, bills, Hansard and so on) is discussed. The majority of the session is self-paced, with students working alongside the rest of their team to identify the material needed to accomplish their task. They are furnished with a set of questions and prompts focussed very clearly on the task, but which models the information seeking process and builds upon the IT and library orientation skills developed earlier in the course. The students explore how to find specific documents on the web, find relevant information within large reports and consider how to record what they find. Before the next seminar, the team must read the information they find, and so the session ends with a team meeting as they discuss the way forward and division of work. Through this session, the students are developing their skills in information literacy Standards 1 and 2: determining a need and accessing the information. They will also be working towards the QAA benchmark standards for law by demonstrating "a basic ability to identify accurately the issue(s) which require researching" and an ability "to identify and retrieve up-to-date legal information" (see Figure 2).

The next stage is to evaluate the information and its sources critically (Standard 3). In the second of the five seminars, now led by a law tutor, each team pools its research before agreeing and presenting a report. The tutor works with each team to consider the relevance of the information found to the assigned task, how authoritative the sources might be, whether they exhibit bias and how the team plan to attribute research material in its report. The correspondence between information literacy Standard 3 and the QAA benchmark 
standards for law is again striking. A specific focus on evaluation of sources accessed fosters skills of analysis, critical judgement and evaluation as set out under "General transferable intellectual skills" in the benchmarks (see Figure 2). Incidentally, students are also developing teamwork skills (see "Key skills" in Figure 2).

Moving on to information literacy Standard 4, students are asked to use the information in two distinct ways in the seminar. First, the team structures an oral report, selecting and using information from an assigned perspective and moulding it to the needs of an assigned audience. Second, the team drafts a short piece of legislation, which requires them to make a different selection and use it in the light of what they have learned earlier in the course about the purposes of legislation, drafting styles, and the problems associated with its interpretation. In meeting information literacy Standard 4, students demonstrate skills in all three areas of performance included within the QAA benchmarks. They must exhibit knowledge and application and problem solving ("Subject specific abilities" in Figure 2); synthesis ("General transferable intellectual skills" in Figure 2) and the "Key skills" of communication and literacy and teamwork (Figure 2).

In the third seminar, the researched information is used again, this time to write an essay. Prior to the class, students are asked to produce an essay plan and write an essay of 1250 words supported by a "research trail". The research trail requires students to reflect upon the process of research by assessing the reliability, objectivity, weight of authority and relevance to the assigned topic of each accessed source used in preparation of the essay. A suggested format is made available to students on the module website. The essay title is :

The right enjoyed by defendants charged with either way offences to elect trial by jury is expensive, inefficient and open to abuse. It should be abolished without delay.

Discuss.

The groups first identify the characteristics of a good essay. Law tutors ensure that particular attention is given to the University's rules on proper citation and the avoidance of plagiarism. Each student then peer reviews another's essay anonymously and produces a report by reference to the criteria they have identified. Students have an opportunity during the following week to re-draft their essay in the light of this student feedback as well as tutor comments on their plan and research trail, before the essay is submitted as unassessed course work. 
These three seminars take students through the stages of information literacy and many of the QAA's law benchmarks with assistance from both law tutors and library staff. The next two reinforce the process by requiring students to complete research tasks without that assistance. For the fourth seminar of the cycle, students are assigned individual topics on the criminal and civil justice system and asked to give a $5-8$ minute presentation. They are required to conduct independent research; to produce a handout properly attributing all sources relied upon for distribution to the group, and encouraged to present their topic rather than merely read it. Students are given the option of using Powerpoint to support their presentation and are given individual feedback by the law tutor. All stages of information literacy are included within the exercise and the seminar enhances student knowledge and understanding of key aspects of the legal system. In addition to reinforcing information literacy, the fourth seminar encourages autonomous learning, as required under "General transferable intellectual skills" in the QAA benchmarks (see Figure 2).

The final seminar takes the form of a moot. Students are assigned to a legal team and given a fallow week to prepare. Again all stages of information literacy inform the task. They are required to determine the information they will need in order to represent their client. This demands use of their skills of legal analysis acquired earlier in the course. They then access relevant primary legal materials and evaluate them, drawing again on their legal skills and use researched secondary sources as necessary. The next stage demands use of the primary legal sources to structure a legally persuasive argument on a client's behalf, while the final stage necessitates good oral communication skills. Students may have to re-evaluate information in the light of arguments presented by opposing counsel, and think on their feet to amend their use of it in response.

\section{Has embedding information literacy produced benefits?}

Adopting a structure developed around the concept of information literacy has allowed us to develop a course which embraces a skills-based approach to student learning without sacrificing substantive content. The module is the start of a process whereby students are enabled to meet the QAA benchmarks for law (Figure 2). Other than numeracy, a course built around information literacy facilitates all the QAA areas of performance. 
The benefits from the law tutor's perspective are clear. Students arrive at classes armed with detailed knowledge and eager to use it. Seminars can be devoted to the higher-order skills of application and problem solving, without the need for dissemination of information or knowledge-based questioning.

Working together, law tutor and librarian can focus on skills of evaluation and use (information literacy Standards 3 and 4) to address the challenge presented to this generation of students by information which increasingly comes in unfiltered formats. Structuring a skills-based module around the framework of information literacy has focused students' attention on evaluation as a discrete and necessary stage in the learning process, and provided a mechanism for law tutors to support students' burgeoning skills. By dedicating a seminar to evaluation of sources, law tutors have been able to work with students, individually and in small groups, to help them make judgements about authority and to synthesise them into a critical response to varied tasks.

Peer and tutor review of essays in a workshop format has enhanced key skills of communication and literacy. Integration into a law module has demonstrated to students the high value placed on standards of literacy by both law tutors and future employers. Students learn to appreciate the importance of editing and redrafting their work, and of proper referencing. The introduction of a "research trail", while encouraging evaluation of sources, has also reduced the incidence of plagiarism. The trail provides a detailed record of all accessed materials and how they have been used. Intentional plagiarism has become more difficult to conceal, while conscious reflection on sources as a necessary stage in the writing process has reduced instances of unintentional plagiarism.

However, integrated skills teaching can offer only limited support for those home and international students who need more specialist or intensive literacy support. For this everincreasing group of students, supplementary "bolt-on" support remains necessary. While for international students at Cardiff this support is available from a full-time language tutor, less help has been available for those home students who are identified as having weak written communication skills. Law tutors, the law librarian, language support tutor and e-learning development officer are currently working to provide more on- line support to meet this growing need. 
The benefits from the law librarian's perspective are also clear. At the library information desk, there has been a marked shift away from those enquiries which indicate a lack of information skills, such as general queries on how to approach researching a task or how to use a database. There is instead a rise in students asking for reminders of passwords and requiring help when there are specific technical difficulties, indicating that the databases are being well used. The same conclusion can be drawn from usage statistics. The suppliers of the key legal databases report that Cardiff is a particularly heavy user of their products. The web page which acts as a portal for legal information in Cardiff and is the vehicle by which students learn to access the databases and relevant web pages is also heavily used. It is one of the top five most well used Information Services web pages, and consistently receives well over 6,000 hits per month during semester time. Most importantly, the benefits to students translate into enthusiastic participation in research-led exercises and a pro-active approach to autonomous learning.

Has embedding information literacy produced benefits for students? Module results confirm the success of an information literacy model of skills-based learning, particularly at the higher end of achievement. The percentage of first class marks awarded for the module has risen from $1.4 \%$ before the module was revised, to $9 \%$ this year. Upper seconds have increased from $16.7 \%$ to $25 \%$, with a small drop in the failure rate from $10.5 \%$ to $9 \%$. Furthermore, students respond very positively to the approach. Levels of preparation and performance in seminars are good. Students clearly engage in the learning process and give positive feedback on module questionnaires, commenting partic ularly on the value of practical support in IT training and developing a research strategy.

\section{Conclusion}

The Cardiff experience has shown that information literacy provides an effective framework upon which to teach legal skills within a substantive law course whilst facilitating the attainment of the QAA benchmarks and requirements of a qualifying law degree. By collaborating, we have been able to draw upon the expertise of law tutor, law librarian and IT specialist to design a module which provides students with a firm foundation for their future legal studies, and which sets them on the path to becoming autonomous and life-long learners. Skills, of course, cannot be "learned" in a single module; nor can students become 
"information literate" in just one semester. Skills must be exercised, and information literacy standards reinforced, as students progress through their university careers. At Cardiff, we believe that we have taken the important first step towards ensuring that all our students graduate with a fully developed skills-set by embedding information literacy into a compulsory first year module. The challenge ahead lies in building it into modules at each level of our degree schemes - this is our aim for the future. 